\title{
Touchdown treatment of root trainer shortened the formation time of root mass of rubber tree seedlings
}

\author{
Xin-long Wang, Xianhong Chen, Jun Wang*
}

Rubber Research Institute, Chinese Academy of Tropical Agricultural Sciences, Danzhou, Hainan 571737, China

* Corresponding author Email: wangjuncatas@163.com

\begin{abstract}
Root trainers are increasingly being used to avoid root coiling and distortion and lack of wind tolerance after field transplanting, when compared to the conventional polybag planting system. Root tips grew out of root trainer forming an intact root mass and then could be transplanted to the field with high survival rate. While the influence of spatial position on root tips growing out of budded stump root trainer was still unknown at nursery stage. Therefore, the bottoms of root trainer were placed in aboveground $(20 \mathrm{~cm}$, current practice), touchdown $(0 \mathrm{~cm})$ and underground $(15 \mathrm{~cm})$ for budded stump nursery, respectively. Clone CATAS 7-20-59 budded stump was raised in root trainer and percentage of plants with root tips outgrowing, growth performance, leaf $N$ content, leaf SPAD, leaf temperature and leaf surface humility were recorded, respectively. The results showed that root trainer touchdown of budded stump gave more percentage in root tips growing out of root trainer, more leaf $N$ content $(P<0.01)$, more leaf SPAD value $(P<0.01)$ and higher leaf surface humility $(P<0.01)$ when compared to underground and aboveground treatments. Thus, touchdown was the optimal choice for rubber budded stump root trainer nursery.
\end{abstract}

Keywords-Hevea brasiliensis, budded stump, root trainer, touchdown, SPAD value.

\section{INTRODUCTION}

High-quality seedlings of Hevea are an important prerequisite for raising good plantations and enhancing the productivity. Root trainers are increasingly being used to avoid coiling and spiraling of roots and improve proliferation of lateral roots and ultimately survival rate and productivity of plants, and three month old plants raised in root trainers showed better growth than those raised in polybags(Soman and Saraswathyamma, 1999). The performance of root trainer plants (raised by planting budded stump) and direct-seeded green-budded polybags were comparable during the initial four years after transplanting in the field, but considering the practical convenience and cost involved, root trainer one-whorl plants appeared to be the ideal planting material for commercial planting of Hevea(Sherin et al., 2013). Root trainer plants of Hevea had only 55 percent less biomass than polybag plants due to the limited space(Sumesh et al., 2015). Root trainer is easy for transportation and transplant saving time and cost for rubber planter. The growth performance of rubber mini-budding raised in polytube was significantly related to the ground clearance(Zhou et al., 2015). Our previous nursery experience showed that root tips grew out of root trainer forming an intact root mass and then rubber budding raised in root trainer could be transplanted to the field with high survival rate(Fig.1), which was a standard rule for rubber root trainer for transplanting. However, the influence of ground clearance on root tips growing out of budded stump root trainer was still unknown.

Soil plant analytical development (SPAD) chlorophyll meter reading (SCMR) is easy to operate, reliable, fairly stable and low cost, and widely used in many crops. SPAD value is positive correlation with chlorophyll content, which can be used for evaluation index instead of chlorophyll content when conducting elimination selection for germplasm sources of Hevea brasiliensis $(\mathrm{Li}$ et al., 2017). SPAD value also is suggested to divide growth phenology of Hevea brasiliensis(Zhang et al., 2019). For rubber root trainer nursery, shortening the time of root mass formation and improving efficiency is vital. Therefore, the present study was carried out to assess the 
influence of spatial position on root tips growing out of root trainer and growth of budded stump root trainer.

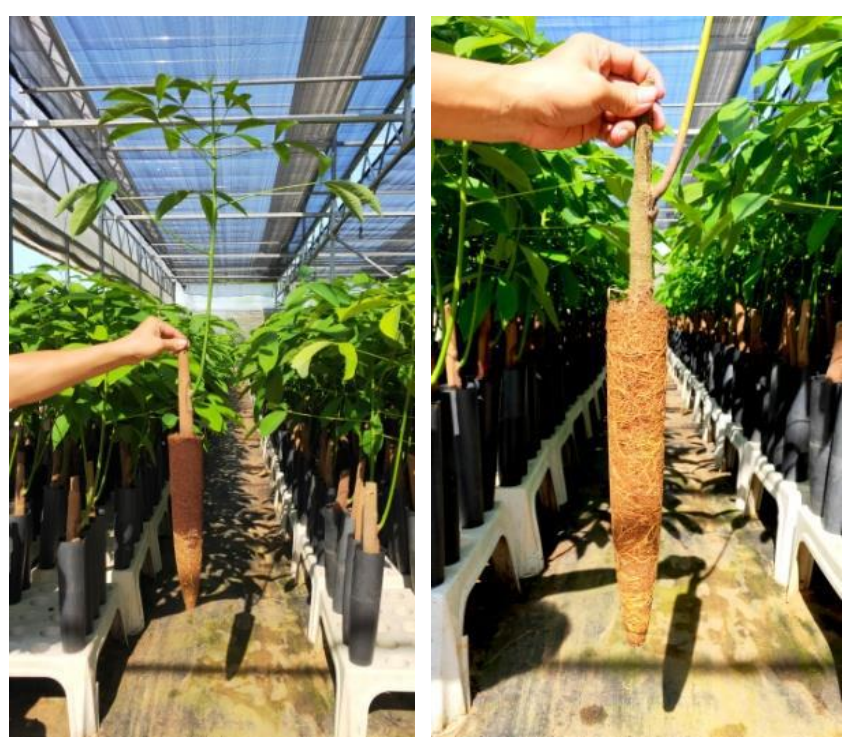

Fig.1: Root mass of budded stump in root trainer

\section{MATERIAL AND METHODS}

The experiment was conducted from October 2018 to June 2020 in the nursery base of natural rubber of Rubber Research Institute of Chinese Academy of Tropical Agricultural Sciences, Danzhou City, Hainan Province, China. Clone GT1 seeds were sown in sand bed for germination and about 20-25 days later the GT1 seedlings as rootstock were transplanted in ground nursery for budded stump nursery and meanwhile root trainer for seedling nursery. The containers are tapering polypropylene cups with a drainage hole at the bottom(top diameter $8 \mathrm{~cm} *$ height $37 \mathrm{~cm} *$ bottom diameter
$2 \mathrm{~cm})$. The budded scion was clone CATAS 7-20-59. After budding successfully, they were raised in root trainer with pure coconut bran. The nursery of budded stump was according to the conventional practices. At nursery stage, the bottom of root trainer were placed in aboveground and touchdown for seedling nursery. While the bottom of root trainer for budded stump nursery were placed in aboveground $(20 \mathrm{~cm}$, current practice), touchdown $(0 \mathrm{~cm}) \quad$ and underground $(15 \mathrm{~cm})$, respectively(Fig2.). Each treatment had three replications, and each replication contained 100 plants. At 2-3 mature leaf whorls stage of rubber seedling, rate of root tips growing out of root trainer at two spatial positions(aboveground and touchdown ) were measured, respectively. At one stable leaf whorl stage of budded stump, non-sprouting rate, diameter, plant height and rate of root tips growing out of root trainer at three spatial positions(aboveground, touchdown and underground) were recorded, respectively. At one mature leaf whorl stage, a Portable Chlorophyll Meter(CY-YL04, China) was used for detecting chlorophyll content(SPAD value), nitrogen content, leaf temperature and leaf surface humidity of plants during 11:00-11:50 and each treatment contained 30 plants. Statistical analyses were performed with data processing system (DPS) statistical software package version 16.5 using one-way ANOVA followed by the Duncan's Multiple Range Test (SSR) to evaluate significant difference among different spatial position of budded stump root trainer. All data were shown in the mean \pm SD of three biological replicates(each replication contained 100 plants for growth performance and 30 plants for Portable Chlorophyll Meter). 

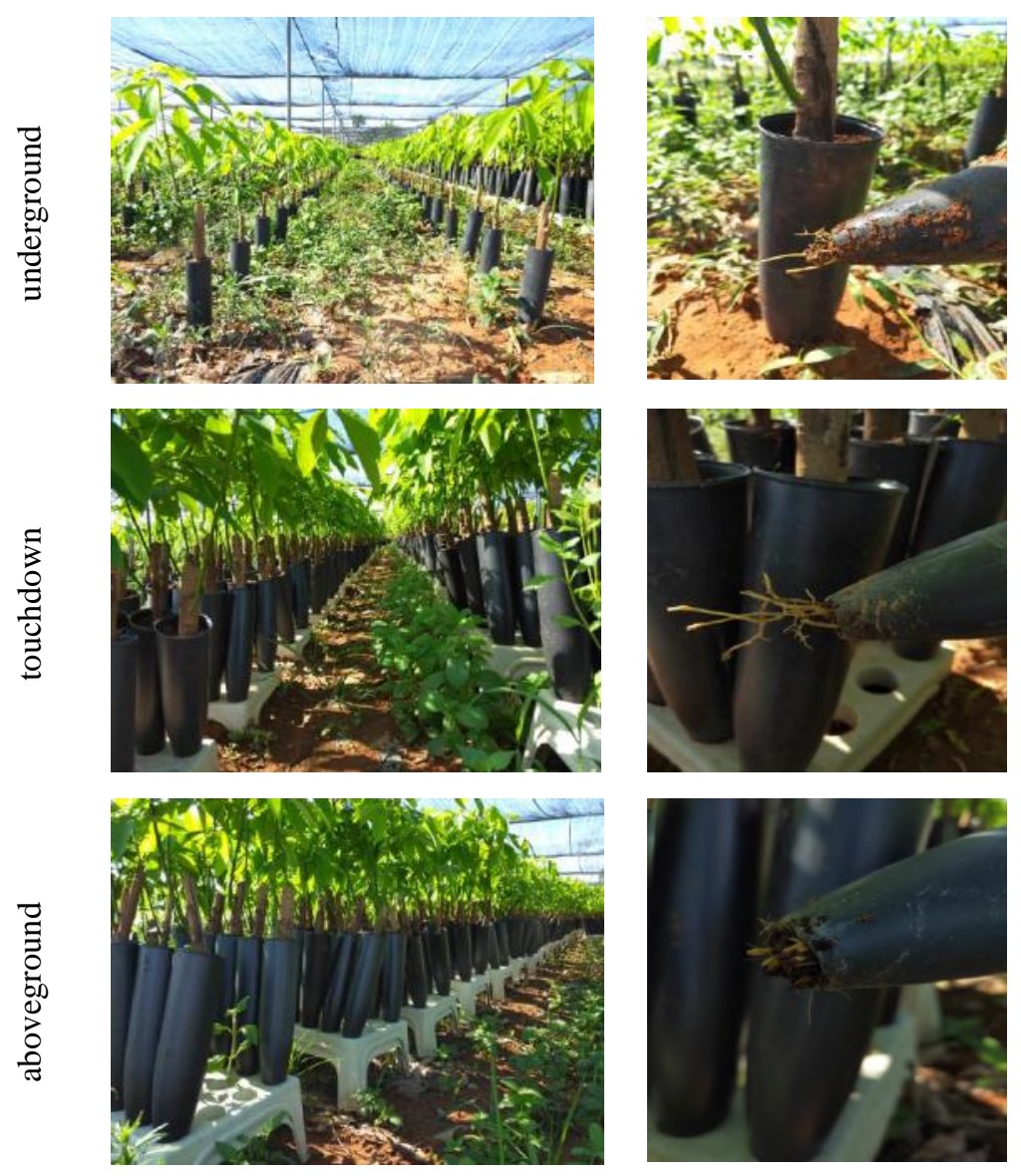

Fig.2: Spatial position of root trainer and root tips of budded stump

\section{RESULT AND DISCUSSION}

Spatial position on percentage of root tips growing out of root trainer As observed in Fig.3A, mini-seedling budding raised in root trainer, showed $80.0 \%$ root tips growing out of root trainer at touchdown and $23.3 \%$ root tips growing out of root trainer at aboveground. While seedling raised in root trainer, recorded $72.6 \%$ root tips growing out of root trainer at touchdown and $4.8 \%$ root tips growing out of root trainer at aboveground. To further investigate the effects of spatial position of root trainer on root tips, budded stump was transplanted in root trainer at underground, touchdown and aboveground (Fig.2), respectively. Seventy-six days after transplanting, root tips of root trainer were checked at stable leaf
stage(Fig.3B). Bud non-sprout percentage of budded stump root trainer were $15.7 \%$ at aboveground, $4.7 \%$ at touchdown, and $7.0 \%$ at underground, respectively. The percentage of root-tips non-growing out of root trainer were $53.7 \%$ at aboveground, $44.0 \%$ at touchdown, and $42.7 \%$ at underground, respectively. The percentage of root-tips growing out of root trainer were $30.7 \%$ at aboveground, $51.3 \%$ at touchdown, and $50.3 \%$ at underground, respectively. In the present observation performed on different types of rubber seedling, the treatment of root trainer touchdown gave more percentage for root tips growing out of root trainer compared to underground and aboveground treatments. 
A

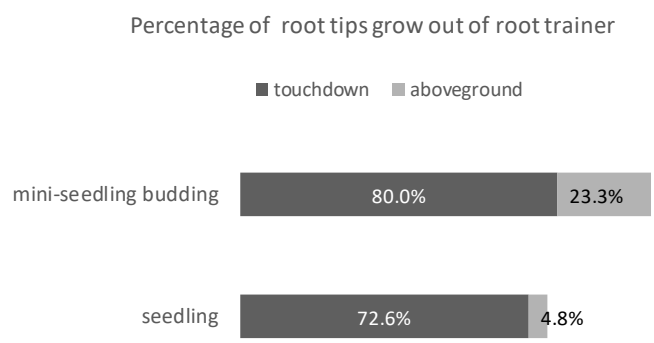

B

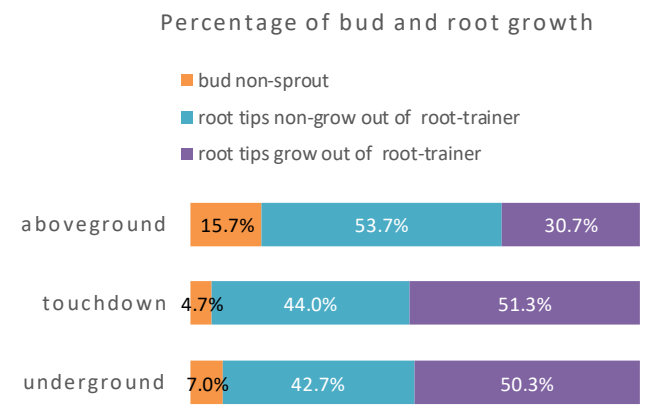

Fig. 3: Percentage of plants with root tips out growing of root trainer at two spatial positions(A) and three spatial positions $(B)$

\section{Spatial position of root trainer on growth of rubber budded stump At one mature leaf whorl stage of budded stump, rootstock diameter, scion diameter and scion height were recorded to check spatial position of root trainer (aboveground, touchdown and underground) on growth performance. There was no significant difference in rootstock diameter and scion diameter among three spatial positions(Fig.4A, B). While scion height of budded stump root trainer at underground was $5.67 \%(\mathrm{P}<0.05)$ and $6.51 \%(\mathrm{P}<0.05)$ less than that at touchdown and at above ground (Fig.4C), respectively.}

There was no significant difference in scion height between touchdown and aboveground. Normally, the first leaf whorl growth of budded stump root trainer was provided by rootstock nutrient, and thus the rootstocks at three spatial positions gave no significant difference, which had no significant difference in scion diameter at the same scion clone. However, scion height of budded stump root trainer at underground was significantly lower than that at other two spatial positions(same plant density), which might induced by plant density for struggling for sunlight(Fig.2) at the same shade.
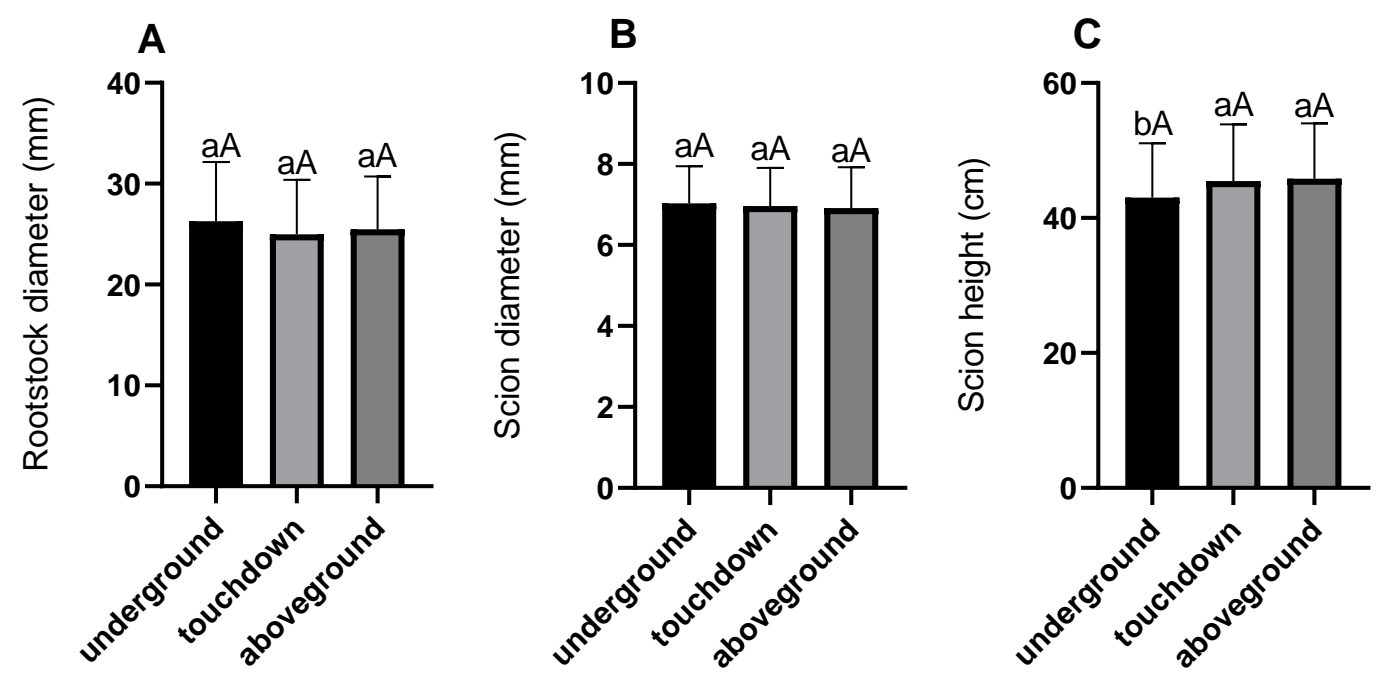

Fig. 4: Spatial position of root trainer on growth of budded stump

\begin{abstract}
Spatial position of root trainer on $\mathrm{N}$ content and SPAD value of budded stump As shown in Fig.5A, leaf $\mathrm{N}$ content of budded stump root trainer at aboveground was $2.45 \%(\mathrm{P}<0.01)$ and $5.20 \%(\mathrm{P}<0.01)$ less than those at underground and at touchdown, respectively. Leaf $\mathrm{N}$ content of budded stump root trainer at underground was
\end{abstract}

$2.60 \%(\mathrm{P}<0.01)$ less than that at touchdown. Similarly, SPAD value was consistent with leaf $\mathrm{N}$ content in the present study. As shown in Fig.5 B, SPAD value of budded stump root trainer at aboveground was $3.02 \%(\mathrm{P}<0.01)$ and $6.29 \%(\mathrm{P}<0.01)$ less than those at underground and at touchdown, respectively. SPAD value of budded stump 
root trainer at underground was $3.18 \%(\mathrm{P}<0.01)$ less than that at touchdown. Comparing with the above results of rootstock and scion growth, there was no significant difference among three spatial positions, but the treatment of root trainer aboveground gave less percentage for root tips growing out of root trainer, which might account for absorbing nutrient from the soil at underground and at touchdown, and thus might cause leaf gave more $\mathrm{N}$ content and SPAD value. Chlorophyll meter can estimate leaf chlorophyll content as a surrogate measure of the nitrogen (N) status of plants to assess the $\mathrm{N}$ requirements of crops and increase nitrogen-use efficiency(Maiti et al., 2004). Moreover, there was a consistent strong and positive correlation SPAD value and net photosynthetic rate(Pn) and thus could be used as surrogate trait for improved Pn under drought conditions(Puangbut et al., 2017; Songsri et al., 2009). Therefore, in the present study, touchdown treatment of root trainer made budded stump grew well than other two spatial positions.
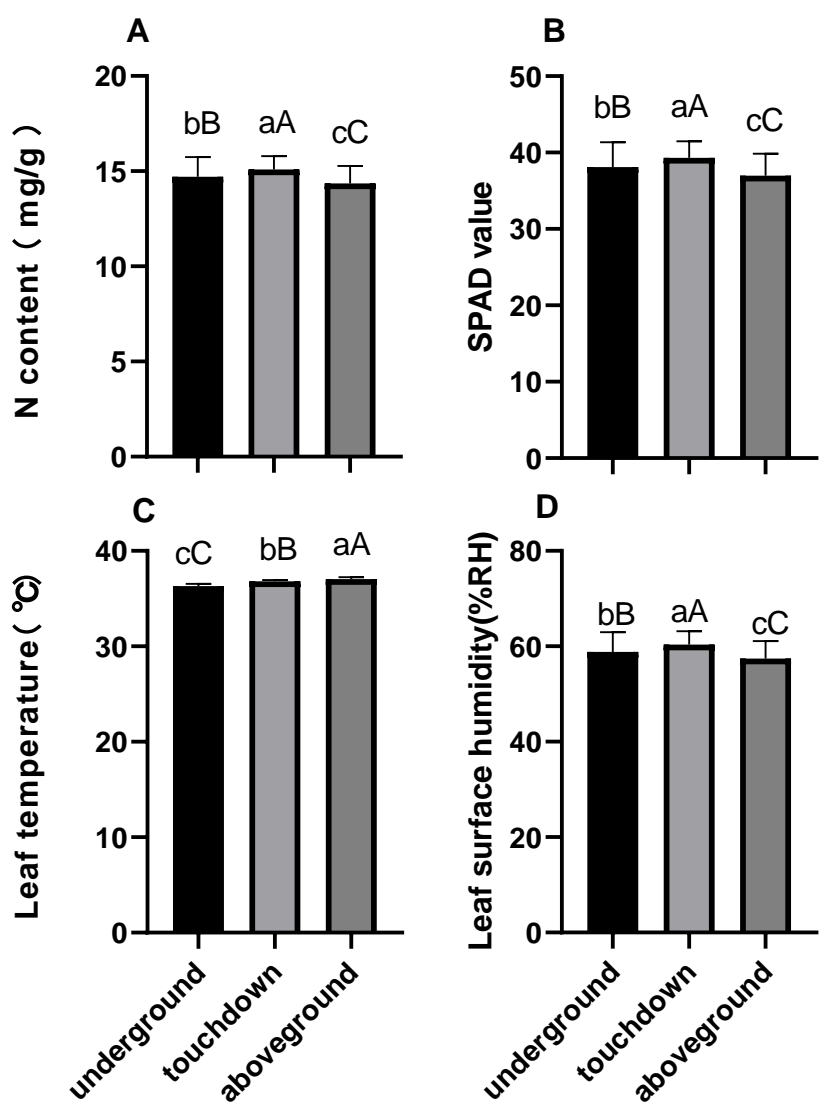

Fig. 5: Spatial position of root trainer on leaf $N$ content, SPAD value, leaf temperature and leaf humidity of budded stump
Spatial position of root trainer on leaf temperature and leaf surface humidity of budded stump As shown in Fig.5C, leaf temperature of budded stump root trainer at aboveground was $1.98 \%(\mathrm{P}<0.01)$ and $0.59 \%(\mathrm{P}<0.01)$ higher than those at underground and at touchdown, respectively. Leaf temperature of budded stump root trainer at touchdown was $1.41 \%(\mathrm{P}<0.01)$ higher than that at underground. On the contrary, as shown in Fig.5D, leaf surface humidity of budded stump root trainer at aboveground was $2.45 \%(\mathrm{P}<0.01)$ and $5.12 \%(\mathrm{P}<0.01)$ less than those at underground and at touchdown, respectively. Leaf surface humidity of budded stump root trainer at underground was $2.54 \%(\mathrm{P}<0.01)$ less than that at touchdown. These results showed that spatial position of root trainer had significant effect on budded stump.

Correlation analysis among $\mathbf{N}$ content, SPAD value, leaf temperature and leaf surface humidity As mentioned in Table 1, SPAD value was significantly correlated with $\mathrm{N}$ content and leaf surface humility $(\mathrm{P}<0.001)$, irrespective of treatments. $\mathrm{N}$ content was also significantly correlated with leaf surface humility $(\mathrm{P}<0.001)$, whatever treatments. Leaf temperature was correlated with SPAD value, $\mathrm{N}$ content and leaf surface humility $(\mathrm{P}<0.05)$ at touchdown treatment. While leaf temperature was not correlated with SPAD value, $\mathrm{N}$ content and leaf surface humility $(\mathrm{P}>0.05)$ at underground and aboveground treatments, respectively. Plant water status must be taken into account to precisely monitor crop SPAD value and $\mathrm{N}$ needs with Chlorophyll Meter(Martínez and Guiamet, 2004; Nigam and Aruna, 2008). Chlorophyll content and SPAD value were reported to be positively correlated with drought resistance in potato (Zhang, 2007) and in Hevea brasiliensis(Yin et al., 2017). In the present study, leaf surface humility was significantly correlated with SPAD value and $\mathrm{N}$ content $(\mathrm{P}<0.001)$, which was consistent with previous study. Moreover, leaf temperature correlated with SPAD value, $\mathrm{N}$ content and leaf surface humility for touchdown treatment was obvious, respectively. 
Table 1 Correlation analysis among SPAD value, $N$ content, leaf temperature and leaf surface humidity of budded stump

\begin{tabular}{|c|c|c|c|c|c|}
\hline $\begin{array}{l}\text { Treatme } \\
\text { nts }\end{array}$ & Factors & $\begin{array}{l}\text { SPA } \\
\text { D } \\
\text { valu } \\
\text { e }\end{array}$ & $\begin{array}{l}\mathbf{N} \\
\text { cont } \\
\text { ent }\end{array}$ & $\begin{array}{l}\text { Leaf } \\
\text { surfac } \\
\text { e } \\
\text { humi } \\
\text { dity }\end{array}$ & $\begin{array}{l}\text { Leaf } \\
\text { tempera } \\
\text { ture }\end{array}$ \\
\hline \multirow[t]{4}{*}{$\begin{array}{l}\text { Undergr } \\
\text { ound }\end{array}$} & $\begin{array}{l}\text { SPAD } \\
\text { value }\end{array}$ & & 0 & 0 & 0.6619 \\
\hline & $\begin{array}{l}\mathrm{N} \\
\text { content }\end{array}$ & $\begin{array}{c}0.99 \\
96\end{array}$ & & 0 & 0.6823 \\
\hline & $\begin{array}{l}\text { Leaf } \\
\text { surface } \\
\text { humidit } \\
\text { y }\end{array}$ & $\begin{array}{c}0.99 \\
96\end{array}$ & 1 & & 0.6823 \\
\hline & $\begin{array}{l}\text { Leaf } \\
\text { tempera } \\
\text { ture }\end{array}$ & $\begin{array}{c}0.05 \\
1\end{array}$ & $\begin{array}{c}0.04 \\
77\end{array}$ & $\begin{array}{c}0.047 \\
7\end{array}$ & \\
\hline \multirow[t]{4}{*}{$\begin{array}{l}\text { Touchdo } \\
\text { wn }\end{array}$} & $\begin{array}{l}\text { SPAD } \\
\text { value }\end{array}$ & & 0 & 0 & 0.0215 \\
\hline & $\begin{array}{l}\mathrm{N} \\
\text { content }\end{array}$ & $\begin{array}{c}0.99 \\
92\end{array}$ & & 0 & 0.0205 \\
\hline & $\begin{array}{l}\text { Leaf } \\
\text { surface } \\
\text { humidit } \\
\text { y }\end{array}$ & $\begin{array}{c}0.99 \\
92\end{array}$ & 1 & & 0.0205 \\
\hline & $\begin{array}{l}\text { Leaf } \\
\text { tempera } \\
\text { ture }\end{array}$ & $\begin{array}{c}0.22 \\
98\end{array}$ & $\begin{array}{c}0.23 \\
15\end{array}$ & $\begin{array}{c}0.231 \\
5\end{array}$ & \\
\hline \multirow[t]{4}{*}{$\begin{array}{l}\text { Abovegr } \\
\text { ound }\end{array}$} & $\begin{array}{l}\text { SPAD } \\
\text { value }\end{array}$ & & 0 & 0 & 0.1189 \\
\hline & $\begin{array}{l}\mathrm{N} \\
\text { content }\end{array}$ & $\begin{array}{c}0.99 \\
95\end{array}$ & & 0 & 0.1171 \\
\hline & $\begin{array}{l}\text { Leaf } \\
\text { surface } \\
\text { humidit } \\
\text { y }\end{array}$ & $\begin{array}{c}0.99 \\
95\end{array}$ & 1 & & 0.1171 \\
\hline & $\begin{array}{l}\text { Leaf } \\
\text { tempera } \\
\text { ture }\end{array}$ & $\begin{array}{c}0.13 \\
1\end{array}$ & $\begin{array}{c}0.13 \\
16\end{array}$ & $\begin{array}{c}0.131 \\
6\end{array}$ & \\
\hline
\end{tabular}

Notes: The lower left corner is the correlation coefficient $r$ and the upper right corner is the $p$ value.

\section{CONCLUSION}

Root trainer touchdown of budded stump gave more percentage in root tips growing out of root trainer, more leaf $\mathrm{N}$ content, more leaf SPAD value and higher leaf surface humility when compared to underground and aboveground treatments. Thus, touchdown was the optimal choice for rubber budded stump root trainer nursery.

\section{ACKNOWLEDGEMENTS}

This work was supported by the earmarked fund for China Agriculture Research System (CARS-34-YZ4).

\section{REFERENCES}

[1] Li, X., F. Zhang, Y. Hu, Y. Qiu, C. Mao, T. Yang, S. Ni, and Y. Wu, 2017: Spatial Distribution Characteristics of Chlorophyll on Different Leaf Positions in Hevea brasiliensis. Journal of Northwest Forestry University 32, 52-58.

[2] Maiti, D., D.K. Das, T. Karak, and M. Banerjee, 2004: Management of nitrogen through the use of leaf color chart (LCC) and soil plant analysis development (SPAD) or chlorophyll meter in rice under irrigated ecosystem. The Scientific World 4, 838-846.

[3] Martínez, D.E., and Guiamet J.J., 2004: Distortion of the SPAD 502 chlorophyll meter readings by changes in irradiance and leaf water status. Agronomie 24, 41-46.

[4] Nigam, S.N., and R. Aruna, 2008: Stability of soil plant analytical development (SPAD) chlorophyll meter reading (SCMR) and specific leaf area (SLA) and their association across varying soil moisture stress conditions in groundnut (Arachis hypogaea L.). Euphytica 160, 111-117.

[5] Puangbut, D., S. Jogloy, and N. Vorasoot, 2017: Association of photosynthetic traits with water use efficiency and SPAD chlorophyll meter reading of Jerusalem artichoke under drought conditions. Agricultural Water Manage 188, 29-35.

[6] Sherin, G., I. Sabu P., S. T. A., and S. V. K., 2013: Field performance of polybag and root trainer rubber plants at different stages of growth. Rubber Science 26.

[7] Soman, T.A., and C.K. Saraswathyamma, 1999: Root trainer nursery for Hevea. Indian Journal of Natural Rubber Research 12, 17-22.

[8] Songsri, P., S. Jogloy, C.C. Holbrook, T. Kesmala, N. Vorasoot, C. Akkasaeng, and A. Patanothai, 2009: Association of root, specific leaf area and SPAD chlorophyll meter reading to water use efficiency of peanut under different available soil water. Agricultural Water Manage 96, 790-798.

[9] Sumesh, K.V., S.K. Soman, K. Annamalalainathan, and J. Jacob, 2015: Physiological comparison of root trainer and polybag plants of Hevea brasiliensis. Journal of Plantation Crops 43, 204-211.

[10] Yin, Z., X. Li, F. Zhang, C. Mao, and Y. Wu, 2017: The identification of Hevea brasiliensis clones to drought resistance by conductivity combined with leaf SPAD value. Tropical Agricultural Science and Technology 40, 6-9+13.

[11] Zhang, F., X. Li, C. Mao, Y. Wu, and S. Ni, 2019: Dynamic Changes of SPAD Value and Color of Hevea brasiliensis Leaves during Different Growth and Development Periods. Journal of Northwest Forestry University 34, 83-90. 
[12] Zhang, W., 2007: Relations between chloropyll content, CAT activity of potato and drought resistance of variety. Research of Agricultural Modenization, 622-624.

[13] Zhou, J., J. Wang, W. Lin, and M. Cai, 2015: Effect of different suspension culture height on rubber mini-polytube budding growth. Chinese Journal of Tropical Agriculture 35, $1-3+8$. 